\title{
IMPLEMENTASI KEBIJAKAN PENGEMBANGAN KOMPETENSI APARATUR SIPIL NEGARA DI KABUPATEN SUMENEP
}

\author{
Rillia Aisyah Haris \\ Program Studi Administrasi Publik, FISIP Universitas Wiraraja Sumenep \\ Email: rilliaharis@gmail.com
}

\begin{abstract}
Policy reform in the development of state civil apparatus competence is the government's commitment to continuously make improvements in the management of civil state apparatus. It aims to produce the optimal performance of the state civil apparatus. Especially in performing public service duties. The commitment is marked by the enactment of Law No. 5 of 2014 on State Civil Apparatus. This study aims to determine the implementation of apparatus competency development policy in Sumenep regency. The research method used is qualitative with descriptive approach. The focus of this research emphasizes the implementation model of Edward III covering communication, resources, disposition, and bureaucratic structure. The result of the research shows that implementation of apparatus competency development policy in Sumenep regency has been implemented effectively.
\end{abstract}

Key words: policy reform; policy implementation; competence development

\section{PENDAHULUAN}

Perubahan kepegawaian menjadi undang-undang aparatur sipil negara merupakan komitmen pemerintah untuk melakukan reformasi kebijakan manajemen aparatur sipil negara dengan dikeluarkannya Undang-Undang No. 5 Tahun 2014 demi memenuhi tuntutan nasional dan tantangan global mewujudkan profesionalisme aparatur sipil negara.

Reformasi kebijakan tersebut antara lain didasari oleh beberapa faktor diantaranya Undang-Undang Nomor 8 Tahun 1974 Tentang Pokok-Pokok Kepegawaian sebagaimana telah diubah dengan Undangundang Nomor 43 Tahun 1999 Tentang Perubahan Atas Undang-Undang Nomor 8 Tahun 1974 Tentang Pokok-Pokok Kepegawaian dinilai sudah tidak sesuai lagi dengan tuntutan nasional dan tantangan global saat ini, kemajuan zaman, ilmu pengetahuan dan teknologi. Sumber daya manusia (SDM) merupakan suatu aset yang berharga bagi suatu organisasi maupun instansi. Oleh sebab itu maka faktor manusia sebagai unsur yang paling penting yang harus dikelola dengan baik melalui perencanaan, pengorganisasian, pengarahan, dan pengawasan serta evaluasi sehingga dapat meningkatkan pengabdian, mutu, keahlian, kemampuan, dan keterampilan dalam melaksanakan tugas secara berdaya guna dan berhasil guna dalam pencapaian tujuan organisasi (Sulistiono: 2013).

Sumber daya manusia dalam hal ini adalah Aparatur sipil negara sebagaimana tertuang dalam Undang-Undang No.5 Tahun 2014 Tentang Aparatur Sipil Negara dimaknai sebagai sebuah profesi yang memiliki kewajiban mengelola dan mengembangkan dirinya, mempertanggungjawabkan 
kinerjanya dan menerapkan prinsip merit dalam pelaksanaan manajemen aparatur sipil negara. Reformasi kebijakan dibidang pengembangan kompetensi aparatur sipil negara penting dilakukan dengan tujuan untuk dapat memiliki layanan sipil yang efektif dan efisien dalam memberikan pelayanan publik. Peninjauan struktur dan kapasitas institusi pemerintah secara menyeluruh menjadi hal yang sangat diperlukan.

Sumber daya aparatur sipil negara merupakan modal yang luar biasa yang bertindak sebagai subyek sekaligus obyek dalam reformasi birokrasi. Sumber daya aparatur sipil negara dengan akal, pengetahuan, kemampuan, serta keterampilan yang dimilikinya sebagai potensi yang patut senantiasa dikembangkan dan ditingkatkan untuk dapat digunakan sebesar-besarnya bagi kemajuan organisasi publik khususnya institusi pemerintah.

Pelaksanaan manajemen aparatur sipil negara selama ini belum berdasarkan pada perbandingan antara kompetensi dan kualifikasi yang diperlukan oleh jabatan dengan kompetensi dan kualifikasi yang dimiliki calon dalam rekruitmen, pengangkatan, penempatan dan promosi pada jabatan sejalan dengan tata kelola pemerintahan yang baik.

Telaah implementasi kebijakan pengembangan kompetensi sumber daya aparatur sipil negara berdasarkan UndangUndang No. 5 Tahun 2014 perlu kiranya dilakukan, sejauh mana kebijakan tersebut mampu menjadi solusi atas perkembangan kebutuhan, tuntutan nasional dan tantangan global terhadap pengembangan kompetensi aparatur sipil negara seperti yang diharapkan.

Beberapa hal tersebut diatas telah menarik perhatian untuk membahas lebih lanjut mengenai implementasi kebijakan pengembangan kompetensi sumber daya aparatur sipil negara khususnya di Kabupaten Sumenep.

Berdasarkan hal tersebut maka perlu dibahas secara mendalam mengenai Bagaimanakah implementasi kebijakan pengembangan kompetensi aparatur sipil negara di Kabupaten Sumenep?

Adapun tujuan dari penelitian ini adalah untuk menganalisa implementasi kebijakan pengembangan kompetensi aparatur sipil negara di Kabupaten Sumenep.

\section{TINJAUAN PUSTAKA \\ Implementasi Kebijakan}

Meter dan Horn sebagaimana dikutip oleh Hiplunudin (2017:36) mendefinisikan implementasi kebijakan publik sebagai tindakan -tindakan yang dilakukan oleh individu-individu atau kelompok-kelompok pemerintah atau swasta yang diarahkan untuk mencapai tujuan yang telah ditetapkan dalam keputusan kebijakan.

Begitu pula dengan Grindle dalam Hiplunudin (2017:37) yang memandang kajian implementasi kebijakan bukan sekedar bersangkut paut dengan mekanisme penjabaran keputusan politik ke dalam prosedur rutin lewat birokrasi lebih dari itu menyangkut masalah konflik, keputusan dan siapa memperoleh apa dari suatu kebijakan.

Dari dua definisi tersebut, Widodo sebagaimana dikutip oleh Herabudin (2016:115) menyimpulkan implementasi 
sebagai proses yang melibatkan sejumlah sumber termasuk manusia, dana, dan kemampuan organisasional yang dilakukan pemerintah ataupun swasta dalam rangka mencapai tujuan yang telah ditetapkan sebelumnya oleh pembuat kebijakan.

\section{Model Implementasi Kebijakan}

Model implementasi kebijakan yang dikembangkan oleh Meter dan Horn (1975) sebagaimana dikutip oleh Hiplunudin (2017:42) menawarkan enam variabel yang membentuk ikatan antara kebijakan dan pencapaian (performance). Model ini tidak hanya menentukan hubungan - hubungan antara variabel-variabel bebas dan terikat mengenai kepentingan-kepentingan, tetapi juga menjelaskan hubungan antara variabel variabel bebas, yaitu:

1) Ukuran dan tujuan kebijaksanaan

2) Sumber-sumber kebijaksanaan

3) Karakteristik dan agen pelaksana

4) Komunikasi antar organisasi terkait dan kegiatan-kegiatan pelaksanaan

5) Sikap para pelaksana

6) Lingkungan ekonomi, sosial dan politik.

Dengan model tersebut Meter dan Horn ingin menguraikan proses dengan cara melihat bagaimana keputusan kebijakan itu dilaksanakan daripada hanya sekedar menghubungkan variabel bebas dan variabel terikat.

Lain halnya dengan model yang dikemukakan oleh Grindle sebagaimana dikutip Hiplunudin (2017:47), model ini ditentukan oleh isi kebijakan (content of policy) dan lingkungan implementasi (context of implementation). Menurut Grindle, variabel isi kebijakan meliputi:
1) Sejauh mana kepentingan kelompok sasaran atau target groups termuat dalam isi kebijakan

2) Jenis manfaat yang diterima oleh target group

3) Sejauhmana perubahan yang diinginkan dari sebuah kebijakan

4) Apakah letak sebuah program sudah tepat

5) Apakah sebuah kebijakan telah menyebutkan implementornya dengan rinci

6) Apakah sebuah program didukung oleh sumber daya yang memadai.

Sedangkan variabel lingkungan implementasi kebijakannya mencakup:

1) Seberapa besar kekuasaan, kepentingan dan strategi aktor yang terlibat dalam implementasi kebijakan

2) Karakteristik institusi dan penguasa

3) Tingkat kepatuhan dan responsivitas kelompok sasaran

Model implementasi yang selanjutnya adalah yang dikemukakan oleh Edward III dalam Nugroho (2009:89) bahwa agar implementasi kebijakan terlaksana secara efektif maka harus memperhatikan empat variabel yaitu:

1) Komunikasi

Bahwa untuk mencapai keberhasilan, implementasi kebijakan mensyaratkan agar implementor mengetahui hal yang harus dilakukan secara jelas. Tujuan dan sasaran kebijakan harus diinformasikan kepada kelompok sasaran sehingga akan mengurangi distorsi implementasi. Hal ini pada umumnya dilakukan melalui kegiatan-kegiatan sosialisasi sebuah kebijakan.

2) Sumber daya 
Implementasi kebijakan harus ditunjang oleh sumber daya, baik itu sumber daya manusia yang memadai, ketersediaan informasi maupun fasilitas-fasilitas pendukung seperti perangkat teknologi informasi, perlengkapan kantor serta sumber dana yang mencukupi untuk pelaksanaan program dan kegiatan.

3) Disposisi

Disposisi disini dimaknai sebagai sikap dan keinginan dari berbagai pihak untuk mendukung suatu kebijakan. Hal ini meliputi komitmen dari seluruh komponen pelaksana kebijakan, aparatur sipil negara dan masyarakat.

4) Struktur birokrasi

Struktur organisasi dimaknai sebagai tatanan organisasi yang mengatur pedoman kerja dan penjabaran wilayah tanggung jawab setiap aparatur pelaksana kebijakan. Salah satu aspek struktur organisasi adalah adanya prosedur operasi yang standar (SOP) yaitu pedoman bagi setiap implementor untuk bertindak.

\section{METODE}

Fokus penelitian ditekankan pada model implementasi kebijakan Edward III sebagaimana dikutip oleh Nugroho (2009:89) meliputi komunikasi, sumber daya, disposisi, dan struktur birokrasi.

\section{HASIL DAN PEMBAHASAN}

Implementasi

kebijakan

pengembangan kompetensi aparatur sipil negara di Kabupaten Sumenep dapat ditinjau dari empat unsur pokok agar implementasi kebijakan tersebut dapat terlaksana secara efektif berdasarkan model implementasi menurut Edward III meliputi:

\section{Komunikasi}

Komunikasi kebijakan merupakan proses penyampaian informasi kebijakan dari pembuat kebijakan kepada pelaksana kebijakan (Widodo, 2011:97). Komunikasi disini dimaknai sebagai proses penyampaian informasi berkenaan dengan tujuan dan sasaran pelaksanaan kebijakan pengembangan kompetensi aparatur sipil negara yang tertuang dalam kegiatankegiatan sosialisasi kebijakan kepada target sasaran. Dalam hal ini yang menjadi target sasaran adalah seluruh aparatur sipil negara di Kabupaten Sumenep.

Berdasarkan hasil penelitian diketahui bahwa jumlah aparatur sipil negara yang menjadi target sasaran dari implementasi kebijakan pengembangan kompetensi ASN di Kabupaten Sumenep per 31 Desember 2016 sebanyak 10.454 pegawai. Dengan jumlah jabatan 2.923 jabatan pelaksana/staf dan 3.647 jabatan fungsional.

\section{Tabel 1}

Persentase Jumlah Pegawai Menurut Tingkat Pendidikan

\begin{tabular}{|c|l|c|}
\hline No & $\begin{array}{c}\text { Tingkat } \\
\text { Pendidikan }\end{array}$ & Prosentase \\
\hline 1. & SD & $3 \%$ \\
\hline 2. & SMP & $2 \%$ \\
\hline 3. & SMA & $31 \%$ \\
\hline 4. & DIPLOMA & $24 \%$ \\
\hline 5. & S1 & $37 \%$ \\
\hline 6. & S2 & $3 \%$ \\
\hline
\end{tabular}

Sumber: BKPSDM Kabupaten Sumenep 2016 
Badan Kepegawaian dan Pengembangan Sumber Daya Manusia Kabupaten Sumenep merupakan institusi yang bertanggungjawab melaksanakan amanah implementasi kebijakan pengembangan kompetensi aparatur sipil negara sebagaimana yang tertuang dalam Undang-undang Nomor 5 Tahun 2014 khususnya pasal 70. Dalam pasal tersebut dinyatakan bahwa setiap aparatur sipil negara memiliki hak dan diberi kesempatan mengembangkan kompetensi melalui diklat, seminar, kursus dan penataran.

Berdasarkan data yang diperoleh pada saat penelitian, sepanjang tahun 2017 telah dilaksanakan beberapa kegiatan diklat baik itu diklat jabatan, diklat non program maupun diklat teknis yang tertuang dalam tabel-tabel berikut ini:

\section{Tabel 2}

Diklat Dalam Jabatan Tahun 2017

\begin{tabular}{|c|c|c|}
\hline No & $\begin{array}{c}\text { Diklat } \\
\text { Kepemimpinan }\end{array}$ & $\begin{array}{c}\text { Jumlah } \\
\text { Peserta }\end{array}$ \\
\hline 1. & Diklat Pim. Tk II & - \\
\hline 2. & Diklat Pim. Tk III & - \\
\hline 3. & Diklat Pim. Tk IV & 40 \\
\hline & Jumlah Total & 40 \\
\hline
\end{tabular}

Sumber: BKPSDM Kab. Sumenep

Tabel 3

Diklat Non Program 2017

\begin{tabular}{|c|l|c|}
\hline No & \multicolumn{1}{|c|}{$\begin{array}{c}\text { Diklat Non } \\
\text { Program }\end{array}$} & $\begin{array}{c}\text { Jumlah } \\
\text { Peserta }\end{array}$ \\
\hline 1. & Eselon II & 1 \\
\hline 2. & Eselon III & 1 \\
\hline 3. & Eselon IV & 42 \\
\hline 4. & Staf & - \\
\hline 5. & Non Eselon & 1 \\
\hline & Jumlah Total & 45 \\
\hline
\end{tabular}

Sumber: BKPSDM Kab.Sumenep

\section{Tabel 4}

Diklat Teknis Tahun 2017

\begin{tabular}{|c|l|c|}
\hline No & Jenis Diklat & $\begin{array}{c}\text { Jumlah } \\
\text { Peserta }\end{array}$ \\
\hline 1. & $\begin{array}{l}\text { Akreditasi } \\
\text { Puskesmas I }\end{array}$ & 40 \\
\hline 2. & $\begin{array}{l}\text { Akreditasi } \\
\text { Puskesmas II }\end{array}$ & 40 \\
\hline & Jumlah Total & 80 \\
\hline
\end{tabular}

Sumber: BKPSDM Kab.Sumenep

Berdasarkan data-data pelaksanaan diklat yang telah dilakukan, dapat diketahui bahwa aspek komunikasi dalam implementasi kebijakan telah terlaksana dengan baik. Serangkaian kegiatan sosialisasi dari UndangUndang No.5 Tahun 2014 telah dilaksanakan oleh Badan Kepegawaian dan Pengembangan Sumber Daya Manusia Kabupaten Sumenep, sehingga seluruh aparatur sipil negara di Kabupaten Sumenep memahami isi dan tujuan dari undang-undang tersebut.

BKPSDM Kabupaten Sumenep selaku implementor dalam kebijakan ini telah mampu melaksanakan amanah dari pembuat kebijakan, mampu memahami isi, tujuan, arah, kelompok sasaran kebijakan, sehingga sebagai implementor kebijakan telah mempersiapkan hal-hal yang berhubungan dengan pelaksanaan kebijakan agar proses implementasi kebijakan pengembangan kompetensi ASN ini bisa berjalan secara efektif dan sesuai dengan tujuan kebijakan itu sendiri.

Komunikasi dalam implementasi kebijakan pengembangan kompetensi aparatur sipil negara ini mencakup beberapa dimensi penting yaitu tranformasi informasi 
(transmisi), kejelasan informasi (clarity) dan konsistensi informasi (consistency). Dimensi transformasi menghendaki agar informasi tidak hanya disampaikan kepada pelaksana kebijakan tetapi juga kepada kelompok sasaran dan pihak terkait. Dimensi kejelasan menghendaki agar informasi yang disampaikan jelas dan mudah dipahami, selain itu untuk menghindari kesalahan interpretasi dari pelaksana kebijakan, kelompok sasaran maupun pihak terkait dalam implementasi kebijakan. Sedangkan dimensi konsistensi menghendaki agar informasi yang disampaikan harus konsisten sehingga tidak menimbulkan kebingungan pelaksana kebijakan, kelompok sasaran maupun pihak terkait.

Dimensi-dimensi tersebut telah terlaksana dengan baik sehingga implementasi kebijakan pengembangan kompetensi ASN yang tertuang dalam program-program kegiatan diklat baik itu diklat dalam jabatan, diklat non program maupun diklat teknis dapat terealisasi dengan baik pula sesuai dengan aturan dan tujuan yang telah ditetapkan.

\section{Sumber Daya}

Peran sumber daya dalam proses implementasi kebijakan sangatlah penting. Apabila kita cermati, seberapa jelas dan konsistensi aturan serta ketentuan dalam sebuah kebijakan, serta keakuratan dalam penyampaian maksud dan tujuan dari kebijakan tersebut, harus tetap didukung oleh ketersediaan sumber daya yang memadai dari para pelaksana kebijakan tersebut.

Implementasi kebijakan ini dapat dikatakan efektif apabila didukung dengan sumber daya yang memadai. Sumber daya yang dimaksud disini berkaitan dengan segala sumber yang dapat digunakan untuk mendukung keberhasilan implementasi kebijakan. Sumber daya ini mencakup sumber daya manusia, anggaran, fasilitas, informasi dan kewenangan.

Demikian pula hal nya dalam implementasi kebijakan pengembangan kompetensi aparatur sipil negara, ketersediaan sumber daya turut memegang peranan penting dalam keberhasilan implementasi kebijakan ini.

$$
\text { Badan }
$$

Kepegawaian

Dan

Pengembangan Sumber Daya Manusia Kabupaten Sumenep didukung oleh sumber daya manusia yang memadai baik secara kualitas maupun kuantitas sebanyak 70 (tujuh puluh) personel dan secara umum memiliki kemampuan dan pengetahuan serta pengalaman yang baik dibidangnya. Hal tersebut dapat dilihat dari tingkat pendidikannya yaitu sebanyak 11 orang adalah berpendidikan Pasca Sarjana (S2) dan 25 adalah berpendidikan Sarjana (S1), sedangkan untuk tingkat pendidikan D III terdapat 4 orang D I terdapat 1 orang dan SLTA sebanyak 27 orang, sedangkan untuk tingkat pendidikan yang paling rendah yakni SLTP sejumlah 2 orang. dengan kata lain bahwa pengetahuan, kemampuan dan kompetensi yang dimiliki ASN dilingkungan Badan Kepegawaian dan Pengembangan Sumber Daya Manusia Kabupaten Sumenep dalam melaksanakan tugas pokok dan fungsinya adalah cukup baik dan potensial.

Implementasi kebijakan tidak akan berhasil apabila tidak didukung dengan sumber daya manusia yang cukup baik secara 
kualitas maupun kuantitas. Kualitas sumber daya manusia berkaitan dengan keterampilan, dedikasi, profesionalitas, dan kompetensi yang dimiliki dibidangnya. Adapun kuantitas berkaitan dengan jumlah sumber daya manusia yang dibutuhkan untuk melingkupi seluruh kelompok sasaran. Aspek sumber daya manusia sangat berpengaruh terhadap keberhasilan implementasi karena tanpa sumber daya manusia yang handal maka implementasi kebijakan akan berjalan lambat dan tidak efektif.

Begitupula hal nya dengan sumber daya anggaran. Dalam implementasi kebijakan, anggaran berkenaan dengan kecukupan modal atau investasi atas suatu program atau kebijakan untuk menjamin terlaksananya sebuah kebijakan. Tanpa dukungan anggaran yang memadai sebuah kebijakan tidak akan berjalan efektif dalam mencapai tujuan dan sasaran yang ditetapkan. Mengingat anggaran merupakan alat bantu manajemen dalam melaksanakan fungsi perencanaan dan pengendalian terhadap sebuah kegiatan. Anggaran berperan sebagai motor penggerak terlaksananya program dan kegiatan.

BKPSDM didukung dengan anggaran yang memadai dalam menjalankan tugas pokok dan fungsinya sehingga program dan kegiatan yang sudah diagendakan dapat terealisasi dengan baik. Terbukti dengan diraihnya beberapa penghargaan diantaranya BKN Award tahun 2017.

Sementara itu ketersediaan sumber daya berupa fasilitas juga merupakan salah satu faktor yang berpengaruh dalam implementasi kebijakan. Pengadaan fasilitas seperti gedung, peralatan perkantoran, perlengkapan akan sangat menunjang dalam keberhasilan implementasi sebuah program dan kebijakan.

Dalam hal ini untuk mendukung pelaksanaan tugas pokok dan fungsinya sebagai implementor kebijakan pengembangan kompetensi aparatur sipil negara sudah didukung dengan sarana dan prasarana yang memadai baik dari segi gedung, peralatan maupun perlengkapan yang dibutuhkan. Telah tersedia gedung Sarana Kegiatan Diklat dengan fasilitas lengkap yang dibutuhkan untuk pelaksanaan diklat.

Disamping itu juga, tidak kalah pentingnya adalah informasi dan kewenangan. Informasi dan kewenangan juga menjadi faktor penting dalam implementasi kebijakan. Dalam ini terutama adalah informasi yang relevan dengan implementasi kebijakan. Sementara wewenang berperan penting terutama untuk meyakinkan dan menjamin bahwa kebijakan yang diimplementasikan berlangsung sesuai dengan harapan yang dikehendaki. Jelas bahwa BKPSDM merupakan institusi yang berwenang menjadi fasilitator dan implementor kebijakan pengembangan kompetensi ASN.

\section{Disposisi}

Kecenderungan perilaku atau karakteristik dari pelaksana kebijakan berperan penting dalam mewujudkan implementasi kebijakan yang sesuai dengan tujuan dan sasaran yang ditetapkan. Karakter penting yang harus dimiliki oleh pelaksana kebijakan meliputi komitmen yang kuat dan kejujuran. 
Badan Kepegawaian Dan Pengembangan Sumber Daya Manusia Kabupaten Sumenep selaku implementor kebijakan pengembangan kompetensi aparatur sipil negara memiliki komitmen yang kuat dalam melaksanakan tugas pokok dan fungsinya terbukti dengan diraihnya penghargaan Diklat Award sejak tahun 2004 hingga saat ini.

Komitmen yang kuat dari implementor kebijakan pada dasarnya akan merangsang mereka untuk selalu antusias dalam melaksanakan tugas, fungsi, wewenang dan tanggung jawab sesuai dengan peraturan yang telah ditetapkan. Sementara itu kejujuran mengarahkan implementor untuk tetap berada pada aturan dan ketentuan program yang harus dilaksanakan.

Sikap dari para implementor kebijakan sangat menentukan keberhasilan implementasi sebuah kebijakan. Apabila implementor memiliki sikap yang baik, maka dia akan dapat menjalankan kebijakan tersebut dengan baik sebagaimana yang diinginkan oleh si pembuat kebijakan. Begitupun hal nya dengan komitmen dan sikap dari Badan Kepegawaian Dan Pengembangan Sumber Daya Manusia Kabupaten Sumenep khususnya bidang pengembangan kompetensi SDM.

\section{Struktur Birokrasi}

Struktur birokrasi merupakan tatanan organisasi yang mengatur pedoman kerja dan penjabaran wilayah tanggung jawab setiap aparatur pelaksana kebijakan. Dalam implementasi kebijakan yang bersifat kompleks menuntut adanya kerjasama dari banyak pihak. Struktur birokrasi harus kondusif terhadap implementasi kebijakan agar kebijakan tersebut dapat terlaksana secara efektif dan tidak ada hambatan yang berarti.

Untuk dapat memahami struktur birokrasi sebagai faktor yang fundamental dalam mengkaji implementasi kebijakan, maka harus dipahami lebih dulu dua karakteristik utama dari birokrasi yaitu:

\section{Standart Operational Procedure (SOP)}

Dalam implementasi kebijakan, struktur organisasi mempunyai peranan penting. Salah satu dari aspek struktur organisasi adalah prosedur operasi yang standar atau SOP. Fungsi dari SOP adalah menjadi pedoman bagi implementor untuk bertindak. Dalam melaksanakan tugas pokok dan fungsinya, Bidang Pengembangan Kompetensi Sumber Daya Manusia Pada Badan Kepegawaian Dan Pengembangan Sumber Daya Manusia Kabupaten Sumenep memiliki SOP yang jelas dalam melaksanakan tugas pokok dan fungsinya, salah satunya adalah SOP pelaksanaan kegiatan Diklatpim IV. Dengan adanya SOP dari setiap program maupun kegiatan maka tujuan dan sasaran dari kegiatan tersebut dapat tercapai secara efektif dan efisien.

\section{Fragmentasi}

Edward III dalam Winarno (2007:155) menjelaskan fragmentasi sebagai penyebaran tanggungjawab suatu kebijakan kepada beberapa badan yang berbeda sehingga membutuhkan koordinasi. Pada umumnya semakin besar koordinasi yang diperlukan dalam implementasi sebuah kebijakan maka akan mengakibatkan tingkat kegagalan dari 
implementasi kebijakan tersebut juga semakin besar. Fragmentasi mengakibatkan pandangan-pandangan yang sempit dari banyak lembaga-lembaga birokrasi yang terlibat. Hal ini mengandung konsekuensi yang cukup merugikan keberhasilan implementasi kebijakan.

Pada tataran ini, BKPSDM sebagai implementor kebijakan pengembangan kompetensi aparatur sipil negara dituntut untuk mampu berkoordinasi secara baik dengan semua pihak yang terlibat dalam implementasi kebijakan. Dalam hal ini adalah semua organisasi perangkat daerah yang ada di Kabupaten Sumenep. Dikarenakan BKPSDM merupakan fasilitator sekaligus implementor yang bertanggung jawab melaksanakan tugas Pengembangan kompetensi sumber daya aparatur sipil negara se kabupaten Sumenep yang meliputi wilayah daratan dan kepulauan. Dalam pelaksanaannya pasti akan menemukan hambatan-hambatan.

Hambatan-hambatan yang pada umumnya terjadi pada fragmentasi birokrasi dalam implementasi kebijakan menurut Winarno (2007:153) yaitu: pertama, tidak ada otoritas yang kuat dalam implementasi kebijakan dikarenakan terpecahnya fungsifungsi tertentu ke dalam lembaga atau badan yang berbeda. Masing-masing badan memiliki yurisdiksi yang terbatas atas suatu bidang, sehingga tugas-tugas yang penting mungkin akan terbengkalai dalam berbagai agenda birokrasi yang menumpuk. Kedua, pandangan yang sempit dari badan atau lembaga yang mungkin juga akan menghambat perubahan. Apabila suatu badan atau lembaga pelaksana memiliki fleksibilitas yang rendah dalam misi- misinya, maka badan tersebut akan berusaha mempertahankan esensinya dan kemungkinan besar akan menentang kebijakan-kebijakan baru yang membutuhkan perubahan.

\section{PENUTUP}

Berdasarkan hasil dan pembahasan diatas, maka dapat ditarik kesimpulan bahwa Implementasi Kebijakan Pengembangan Kompetensi Aparatur Sipil Negara Di Kabupaten Sumenep telah terlaksana dengan baik. Hal tersebut ditinjau dari model implementasi kebijakan Edward III meliputi aspek komunikasi, sumber daya, disposisi dan struktur organisasi.

Adapun rekomendasi yang dapat penulis sampaikan berkaitan dengan implementasi kebijakan pengembangan kompetensi aparatur sipil negara di Kabupaten Sumenep untuk dapat mempertahankan segala prestasi yang telah diraih selama ini oleh Badan Kepegawaian Dan Pengembangan Sumber Daya Manusia Kabupaten Sumenep khususnya pada implementasi pengembangan kompetensi ASN melalui diklat maka perlu dilakukan upaya peningkatan terhadap aspek-aspek yang berpengaruh dalam keberhasilan implementasi kebijakan meliputi :

1. Peningkatan aspek komunikasi dengan inovasi-inovasi baru menggunakan teknologi informasi.

2. Peningkatan aspek sumber daya baik itu sumber daya manusia, anggaran maupun fasilitas.

3. Peningkatan aspek disposisi melalui komitmen yang kuat terhadap pentingnya pengembangan kompetensi ASN 
4. Peningkatan aspek struktur organisasi meliputi standart operational procedure yang efektif dan efisien serta mengurangi dan meminimalisir fragmentasi yang dapat merugikan implementasi kebijakan.

\section{DAFTAR PUSTAKA}

Dunn, W.N. 2000. Pengantar Analisis Kebijakan Publik. Yogyakarta: Gajah Mada University Press

Fadillah. 2005. Paradigma Kritis Dalam Studi Kebijakan Publik. Yogyakarta: Pustaka Pelajar

Herabudin. 2016. Studi Kebijakan Pemerintah Dari Filosofi Ke Implementasi. Bandung: Pustaka Setia

Hiplunudin, Agus. 2017. Kebijakan, Birokrasi Dan Pelayanan Publik. Yogyakarta: Calpulis

Nugroho, Riant. 2009. Public Policy: Dinamika kebijakan, Analisis Kebijakan, Manajemen Kebijakan. Jakarta: Gramedia

Santoso, Amir. 2008. Analisis Kebijakan Publik: Suatu Pengantar. Jakarta: Gramedia

Undang-Undang No. 5 Tahun 2014 Tentang Aparatur Sipil Negara.

Widodo, Joko. 2007. Analisis Kebijakan Publik. Malang: Bayumedia Publishing

Winarno, Budi. 2007. Teori dan Proses Kebijakan Publik. Yogyakarta: Media Pressindo 